Vol. 24, No. 3, Juli 2021, hlm. 412-426

p-ISSN: 1410-9344; e-ISSN: 2549-5631

WARTA LPM

homepage: http://journals.ums.ac.id/index.php/warta

\title{
Peningkatan Kinerja UMKM Selama Pandemi Covid-19 melalui Penerapan Inovasi Produk dan Pemasaran Online
}

\author{
Tri Hanifawati, Ratna Sari Listyaningrum \\ Universitas Muhammadiyah Bandung \\ Email: trihanifawati@gmail.com
}

\section{Article Info}

Submitted: 19 November 2020

Revised: 9 March 2021

Accepted: 12 April 2021

Published: 20 July 2021

Keywords: MSMEs performance, covid-19, product innovation,

internet marketing, social media marketing
Kata kunci: kinerja UMKM, covid-19, inovasi produk, pemasaran internet, pemasaran sosial media

\begin{abstract}
MSMEs are the sector that has been the worst affected by the corona pandemic, where the MSME partner is one of them. The main problem of our partner was sales declined which impacted on a negative revenue, so that two of their employees have been temporarily laid off. The program's aim is to transfer science and technology to the MSME partner in the framework of improving its' business performance. The solution focused on two aspects, namely online marketing management and production management. The methods that have been implemented including new variant innovation, mentoring of production management, new packaging innovation, provision of production tools and raw materials, marketing management coaching, social media promotion, sales on the marketplace, and brand awareness survey. The results show that the knowledge and skills of the partner in the production and marketing aspects have improved. The number of assets and product variants have increased, and the sales trend started to rise. However, the survey results show that MSME still needs to intensify its promotional programs to increase sales from new potential consumers or markets.
\end{abstract}

\begin{abstract}
Abstrak
UMKM merupakan sektor yang terdampak paling buruk oleh pandemi Covid-19, di mana mitra program ini merupakan salah satu yang terdampak. Adapun masalah utama mitra adalah menurunnya tingkat penjualan yang berefek pada penurunan kapasitas produksi dan pendapatan, sehingga dua dari empatkaryawannyaharus diberhentikan dulu untuk sementara. Tujuan pengabdian ini adalah untuk melakukan transfer Iptek kepada UMKM dalam kerangka meningkatkan kinerja bisnisnya. Solusi permasalahan difokuskan pada dua aspek, yakni manajemen pemasaran online dan manajemen produksi. Metode yang telah dilaksanakan diantaranya inovasi varian baru, mentoring manajemen produksi, inovasi kemasan baru, pemberian bantuan alat dan bahan, pembinaan manajemen pemasaran, promosi melalui sosial media, penjualan melalui marketplace, dan survei kesadaran merek.
\end{abstract}


Hasilnya menunjukkan bahwa pengetahuan dan keterampilan mitra dalam aspek produksi dan pemasaran telah meningkat, jumlah aset dan jumlah varian rasa produk telah meningkat, tren penjualan juga telah mulai meningkat. Namun demikian, hasil survei menunjukkan bahwa UMKM masih perlu secara intensif meningkatkan program promosi untuk meningkatkan penjualan dari konsumen atau pasar potensial yang baru.

\section{PENDAHULUAN}

Covid-19 telah menyebabkan perubahan negatif terhadap kinerja ekonomi di tingkat global dan nasional. Beberapa sektor terdampak signifikan adalah transportasi, pariwisata, perdagangan, kesehatan serta beberapa sektor lainnya, di mana sektor yang terdampak paling buruk adalah industri rumah tangga dan UMKM (Susilawati, Falefi, \& Purwoko, 2020). Terdapat setidaknya 37 ribu UMKM di Indonesia yang telah mengalami penurunan kinerja akibat Covid-19, dengan dampak yang ditimbukan adalah penurunan penjualan (56\%), pendanaan (22\%), distribusi barang (15\%), dan akses bahan baku (4\%) (Rahman, 2020).

UMKM mitra sasaran termasuk salah satu yang terdampak signifikan. Mitra kami adalah UMKM produsen eggroll kentang g-Lis 114 di Kampung Citere, Desa Sukamanah, Pangalengan, Bandung, yang telah berdiri sejak tahun 2016. Kentang merupakan salah satu komoditas unggulan di Pangalengan, sehingga mengolah kentang menjadi eggroll merupakan salah satu strategi untuk meningkatkan nilai jual kentang dari petani lokal. Saluran utama penjualannya adalah toko oleh-oleh di wilayah Bandung sehingga saat toko-toko tersebut menghentikan kegiatan penjualannya sementara, maka permintaan terhadap produk mitra juga menurun. Tingkat produksi mengalami penurunan signifikan dari yang semula mencapai 180-300 kg/bulan turun hingga lebih dari 50\%. Modal kerja juga menurun, sehingga untuk tetap beroperasi, UMKM mengurangi sementara jumlah karyawan tetap yang semula 4 orang menjadi 2 orang, memperbolehkan karyawan untuk bekerja dari rumah saat di awal pademi, dan berusaha untuk meningkatkan penjualan dengan menambah mitra penjualan baru. Kelemahannya adalah UMKM hanya mengandalkan promosi dari mulut ke mulut.
Mereka pernah memiliki sosial media namun tidak dimutakhirkan. Adapun metode penjualan utama adalah konsinyasi dan sudah memiliki satu toko milik sendiri.

Dari aspek inovasi produk, mitra telah memiliki varian eggroll yang cukup bervariasi baik dari segi varian rasa maupun ukuran. Varian rasa meliputi original, coklat, green tea, dan pandan yang dikemas dengan bahan toples plastik dengan ukuran 135g, 250g (permintaan tertinggi), 500g, dan $1 \mathrm{~kg}$. Kemasan sudah dilengkapi dengan label yang cukup eye catching, kelemahannya adalah biaya kemasan cukup tinggi mencapai $>20 \%$ biaya produksi, sehingga menyebabkan biaya produksi juga tinggi. Artinya, kemampuan mitra untuk mendapatkan keunggulan biaya masih rendah. Owner juga menyebutkan bahwa perkiraan keuntungan dari satu toples ukuran 250 g hanya berkisar Rp2000/toples. Sayangnya, pilihan varian rasa masih terbatas, padahal kemampuan industri makanan untuk menyediakan banyak varian produk merupakan strategi paling persuasif untuk menjaga loyalitas konsumen. Mitra juga masih memiliki sarana pendukung produksi dan operasional yang terbatas misalnya mixer adonan yang dimiliki hanya satu buah dan rusak baru-baru ini. Produk retur dari toko mitra seringkali tidak diolah lebih lanjut karena keterbatasan alat produksi untuk mengolah produk retur.

Peningkatan kinerja bisnis dapat dilakukan melalui berbagai strategi diantaranya adalah inovasi produk (Curatman, 2016; Haryono \& Marniyati, 2017), penguasaan skill pemasaran (Takata, 2016; Acosta, Crespo, \& Agudo, 2018), pengelolaan keuangan (Popa, Soto-Acosta, \& Perez-Gonzalez, 2018), dan kemampuan kepemimpinan bisnis (Chadwick \& Dawson, 2018). Selain itu, penerapan teknologi digital dalam bisnis ditemukan berdampak signifikan 
terhadap kinerja keuangan UMKM (Popa et al., 2018), di mana UMKM yang mampu menggunakan internet, kekuatan bisnisnya tumbuh 46\% lebih tinggi dari yang dijalankan secara konvensional (Yannopoulos, 2011). Bahkan menariknya, UMKM yang terintegrasi dengan teknologi digital umumnya lebih mampu bertahan saat terjadi krisis (Bouwman, Nikou, Molina-Castillo, \& de Reuver, 2018; Bouwman, Nikou, \& de Reuver, 2019; AICD, 2020). Sebagai contoh, saat Covid-19 mulai menyebar secara masif dan bahkan disebut telah menyebabkan resesi di beberapa negara termasuk Indonesia, sebagian UMKM yang mengubah model bisnis mereka dengan menciptakan layanan dan atau produk baru, mengubah cara pengiriman produk atau layanan ke layanan online, mengubah strategi branding menjadi berbasis internet, dan berinvestasi pada teknologi dan sistem digital terbukti lebih mampu mempertahankan dan bahkan meningkatkan kinerjanya di masa pandemi dibandingkan yang tidak mengadopsi perangkat lunak sama sekali (AICD, 2020; Ludwig, 2020).

Perilaku konsumen juga telah mengalami banyak perubahan sejak era digital dan terlebih di masa Covid-19, diantaranya adalah meningkatnya intensitas belanja online dan penggunaan sosial media (Razdan, Potia, Wintels, \& Dadwal, 2020; Accenture, 2020). Saat ini, orang-orang lebih banyak membelanjakan uang secara online sehingga menggeser inovasi bisnis ke sumber pendapatan digital dan saluran digital (Casalino, Żuchowski, Labrinos, Munoz Nieto, \& Martín, 2020). Sosial media adalah platform yang paling banyak digunakan untuk berinterkasi dengan brand atau perusahaan karena memiliki fiturfitur yang interaktif (Muninger, Hammedi, \& Mahr, 2019), di mana intensitas penggunaannya meningkat tajam selama Covid-19 (Socialbakers, 2020; Lamba, 2020). Melalui platform ini, brand dapat menerima saran dan feedback lebih cepat dari konsumen untuk pengembangan produk atau layanan (Kabadayi \& Price, 2014). Platform ini juga mampu menyediakan sumber data dan bisnis inteligen dalam bentuk analisa saran atau feedback dari konsumen dan insight pasar yang dapat digunakan sebagai acuan dalam proses inovasi pengembangan bisnis (Dai et al., 2015; Muninger, Hammedi \& Mahr, 2019; Hanifawati, Ritonga \& Puspitasari, 2019).
Iklan di sosial media merupakan salah satu fitur yang dapat digunakan untuk meningkatkan penjualan. Terdapat beberapa strategi untuk menghasilkan iklan yang efektif, yakni profil, adalah hal utama yang akan dilihat oleh user saat menemukan sebuah iklan, sehingga profil perlu dibuat menarik dan trusted, misalnya dengan menggunakan akun bisnis, gunakan nama merek sebagai nama akun, dan lengkapi profil dengan alamat website seperti link toko online atau nomor kontak admin. Kedua, sajikan konten visual yang menarik atau bermanfaat untuk target segmen yang dimutakhirkan secara berkala sebelum memulai sebuah iklan. Selanjutnya, konten untuk iklan dapat dipilih dari salah satu post yang memiliki insight tertinggi atau dengan membuat sebuah post baru. Ketiga, sajikan caption yang menarik dan terstruktur sesuai tujuan iklan, umumnya memuat judul/ headline iklan, isi pesan, call to action, dan hastag. Keempat, tentukan target audience iklan sesuai dengan profil segmen pasar dari merek/produk yang akan dipromosikan dan mulai mempromosikan produk. Pantau kinerja iklan dan lakukan analisa terhadap engagement dari calon konsumen dan kinerja penjualan.

Selama Covid-19, kemampuan perusahaan untuk mempromosikan produk melalui paidpromote di sosial media dilaporkan menurun, tetapi posting organik dilaporkan meningkat, yang berarti bahwa strategi organik menjadi pilihan strategis untuk tetap terhubung dengan konsumen dengan biaya yang lebih rendah (Socialbakers, 2020). Tren strategi organik tentunya juga dapat digunakan oleh UMKM yang relatif memiliki anggaran terbatas. Strategi lain untuk sukses bisnis di sosial media adalah kemampuan menciptakan konten yang menarik, konsistensi waktu posting secara berkala, dan kemampuan membangun komunikasi dua arah dengan konsumen (Hanifawati, Ritonga, et al., 2019).

Selain menguasai skill pemasaran, kemampuan inovasi produk juga merupakan peran penting dalam peningkatan daya saing industri makanan. Inovasi produk makanan dapat meliputi inovasi gizi, inovasi rasa, dan inovasi bahan baku (Zuhal, 2013), inovasi kemasan, dan inovasi pada pengolahan produk pangan 
lokal karena ketergantungan industri pada bahan baku impor sering menjadi ancaman bagi perkembangan industri makanan (Hanifawati \& Suryantini, 2015). Produk yang baik harus dikemas dengan kemasan yang menarik, sebab kemasan merupakan silent salesman, di mana hampir keseluruhan atributnya berpengaruh terhadap setiap tahapan keputusan pembelian konsumen (Hanifawati, Suryantini, \& Mulyo, 2017). Inovasi kemasan yang meliputi perancangan konsep, perancangan desain, bahan, dan orientasi segmen pasar merupakan strategi yang efektif untuk meningkatkan daya saing produk. Selanjutnya, inovasi varian rasa bertujuan untuk memberikan alternatif pilihan rasa baru disaat konsumen bosan terhadap produk lama sehingga mereka tetap loyal terhadap merek tersebut. Penelitian menemukan bahwa motivasi utama konsumen beralih merek produk makanan karena menginginkan variasi atau sesuatu yang baru (Hanifawati, Dewanti, \& Saputri, 2019).

Berdasarkan analisa permasalahan mitra dan analisa strategi atau implikasi manajerial dari penelitian terdahulu, maka solusi bagi mitra untuk meningkatkan kinerja bisnisnya adalah melalui penerapan pemasaran internet dan pengembangan inovasi produk. Metode pelaksanaan dilakukan melalui beberapa pendekatan antara lain pembuatan varian rasa baru yang sedang hits (salted egg dan seaweed), redesign kemasan untuk meminimumkan biaya produksi, bantuan alat produksi, serta promosi dan branding melalui sosial media dan meningkatkan penjualan melalui marketplace. Adapun komponen kunci dalam peningkatan pengetahuan, keterampilan, dan manajemen usaha mitra adalah melalui pelatihan bisnis yang mencakup mentoring, transfer iptek, pelatihan berbasis praktik, dan pengembangan prototipe produk. Pendekatan tersebut dinilai lebih efektif dalam mengembangkan skill (AlAwlaqi, Aamer, \& Habtoor, 2018), kompetensi dan motivasi berwirausaha (Mahendra, Djatmika, \& Hermawan, 2017; Barba-sánchez \& Atienza-sahuquillo, 2018), meningkatkan kemampuan inovasi, pengambilan keputusan, dan kemampuan menangkap peluang baru untuk mengembangkan produk atau pasar baru (Al-Awlaqi, et al., 2018).

Tujuan kegiatan pengabdian ini dengan demikian adalah untuk melakukan transfer iptek guna meningkatkan daya saing UMKM mitra, dalam aspek manajemen pemasaran online dan manajemen produksi. Pelaksanaan kegiatan telah dilaksanakan secara bertahap dengan rincian kegiatan sebagaimana dijelaskan pada bagian metode dan hasil kegiatan sebagaimana dijelaskan pada bagian hasil dan pembahasan. Adapun manfaat yang telah dirasakan oleh mitra dari program ini antara lain peningkatan pengetahuan dan keterampilan dalam aspek manajemen pemasaran dan manajemen produksi, peningkatan jangkauan pemasaran, omset, jumlah aset, dan jenis produk.

\section{METODE}

Metode pelaksanaan kegiatan telah dilakukan melalui beberapa tahapan sebagaimana ditunjukkan dengan diagram alir pada Gambar 1. Adapun waktu pelaksanaan kegiatan pengabdian ini dimulai dari Juni 2020 sampai Oktober 2020.

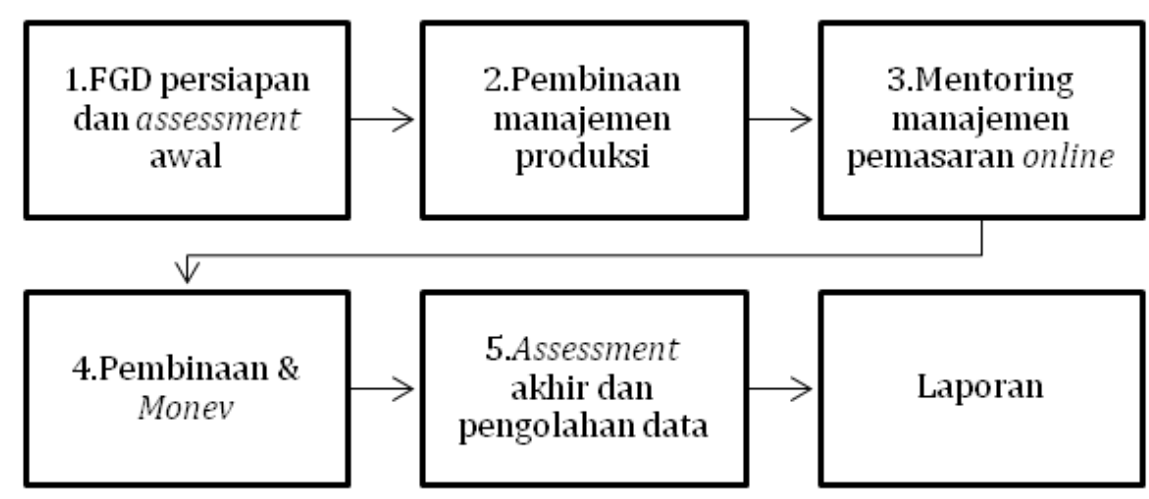

Gambar 1. Tahapan Pelaksanaan Kegiatan PKM 
a. FGD persiapan dan assessment awal

FGD persiapan bertujuan unntuk memberikan sosialisasi tahapan dan metode pelaksanaan kegiatan kepada UMKM sehingga terbangun kesamaan persepsi, tujuan, serta luaran yang akan dicapai di akhir kegiatan baik luaran yang harus dicapai oleh tim pelaksana maupun oleh UMKM. Adapun assessment awal diberikan dalam bentuk pengisian kuesioner dan observasiuntuk mengetahui kondisi terbaru UMKM mengingat jarak antara penyusunan proposal dan dimulainya kegiatan cukup panjang sehingga besar kemungkinan adanya perubahan signifikan yang terjadi di UMKM terlebih di masa pandemi ini.

b. Pembinaan manajemen produksi

Kegiatan ini meliputi redesign kemasan yang tujuan utamanya adalah untuk menurunkan biaya produksi, pemberian bantuan alat produksi, serta inovasi varian eggroll rasa telur asin dan rumput laut. Pelaksanaan mentoring dilakukan secara online melalui Zoom Meeting sebanyak dua kali pertemuan, sedangkan praktik pembuatan produk dilakukan satu kali secara luring di rumah produksi UMKM. Evaluasi capaian luaran diukur dengan melakukan assessment terhadap pengetahuan dan keterampilan mitra dalam aspek manajemen produksi sebelum dan sesudah program, jumlah aset mitra sebelum dan sesudah program, jumlah varian produk mitra sebelum dan sesudah program, serta kapasitas produksi mitra sebelum dan sesudah program.

c. Mentoring manajemen pemasaran online Kegiatan mentoring pemasaran dilakukan secara intensif dan bertahap melalui Zoom Meeting sebanyak 8 kali pertemuan yang fokus pada pengelolaan marketplace dan sosial media, serta dua kali pertemuan luring berupa praktik fotografi produk dan pembuatan iklan di sosial media dan marketplace. Materi daring yang diberikan berupa simulasi dan skill praktis. Bantuan satu buah laptop diberikan untuk menunjang kegiatan pemasaran online mitra. Evaluasi capaian luaran diukur dengan melalui assessment dan observasi terhadap pengetahuan dan keterampilan mitra dalam aspek manajemen pemasaran online sebelum dan sesudah program, adanya bukti update konten di toko online dan sosial media, serta peningkatan jumlah penjualan dan jangkauan pemasaran.

d. Pembinaan dan monev

Ini merupakan tindak lanjut dari kegiatankegiatan mentoring tersebut, yang dilakukan dalam bentuk pendampingan implementasi hasil mentoring. Hal ini bertujuan untuk memastikan bahwa mitra dapat menerapkan pengetahuan dan keterampilan baru-nya dengan baik. Media komunikasi yang digunakan adalah Whatsapp dan kunjungan luring kepada mitra.

e. Assessment akhir dan pengolahan data

Ini bertujuan untuk memastikan tingkat ketercapaianluarandarisetiapimplementasi kegiatan di tingkat mitra. Assessment akhir dilakukan melalui wawancara kepada mitra dan observasi dengan melihat hasil pencatatan keuangan, kinerja pemasaran, dan bukti pembelian aset, serta assessment secara tertulis dalam bentuk pengisian angket atau survei dengan skala likert titik 5 untuk mengetahui persepsi hasil kegiatan sebelum dan sesudah program. Data hasil assessment diolah secara kuantitatif dan kualitatif deskriptif.

\section{HASIL DAN PEMBAHASAN}

\section{Aspek Manajemen Produksi}

Pada aspek manajemen produksi, hasil menunjukkan bahwa setelah terdapat peningkatan pada aspek pengetahuan, keterampilan, jumlah varian produk, dan jumlah aset mitra antara sebelum dan sesudah program (Gambar 1).

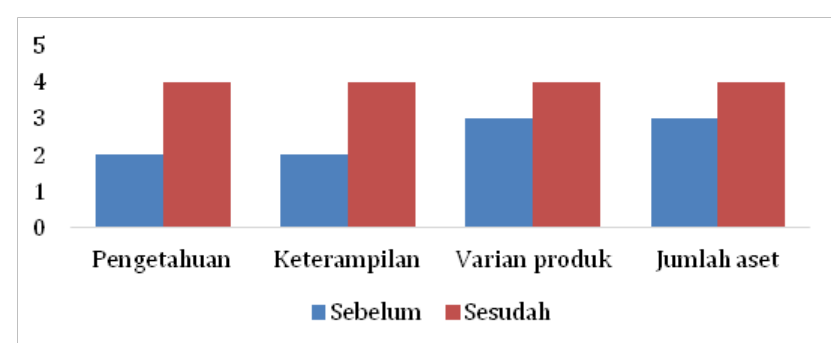

Gambar 1. Dampak pada Aspek Manajemen Produksi Sebelum dan Sesudah Program 
Pengetahuan dan keterampilan baru yang telah diperoleh UMKM antara lain :

a. Dokumentasi bahan baku. Sebelum kegiatan, mitra belum mengetahui pentingnya dokumentasi bahan baku dalam komposisi produk. Kelemahan pendokumentasian inilah yang sering menyebabkan kualitas produk UMKM tidak konsisten seiring waktu atau seiring penambahan volume produksi. Perubahan bahan baku atau komposisinya akan mengakibatkan perubahan pada produk yang dihasilkan, sehingga penggunaannya perlu konsisten. Salah satu cara menjaga konsistensinya adalah dengan melakukan pendokumentasian atau pencatatan pada setiap perubahan. Dokumentasi ini dapat dijadikan acuan pada proses pengembangan produk berikutnya.

b. Dokumentasi alat produksi. Sebelum program, mitra belum mengetahui pentingnya pendokumentasian alat produksi. Dalam kegiatan produksi, peralatan berkaitan dengan maintenance alat, sehingga jika terjadi kerusakan akan mengganggu jalannya proses produksi. Dokumentasi alat produksi sangat membantu UMKM untuk mengetahui umur ekonomis alat tersebut. Dengan cara ini, mitra dapat melakukan persiapan pembelian alat baru sejak dini melalui alokasi biaya penyusutan alat, sehingga tidak akan mengganggu jalannya proses produksi.

c. Dokumentasi proses produksi. Sebelum program, mitra belum mengetahui pentingnya proses produksi, padahal tahapan ini sangat menentukan mutu produk. Sama halnya dengan perubahan bahan baku, perubahan proses produksi akan berpengaruh terhadap kualitas produk akhir, sehingga jika terjadi perubahan maka perlu didokumentasikan sebagai acuan pengembangan produk lebih lanjut.

d. Mitra telah memiliki PIRT, namun belum melakukan pemeriksaan rutin terkait aspekaspek Cara Pengolahan Pangan yang Baik pada Industri Rumah Tangga (CPPB-IRT). Melalui program ini, tim pelaksana telah membuat dan memberikan sebuah buku pedoman CPPBT-IRT yang dapat digunakan sebagai acuan untuk pemeriksaan secara berkala oleh mitra.

e. Mitra sudah diberikan pengetahuan tentang Hazard Analytical Control Point (HACP). Sebelum program, mitra telah mengetahui tentang HACCP namun belum memahami sepenuhnya. Saat ini mitra sudah mulai membentuk tim penjamin mutu dan mampu membedakan bahaya fisik, kimia, dan biologis pada produk pangan.

Selain peningkatan pada aspek pengetahuan, mitra juga telah menghasilkan dua varian produk baru rasa telur asin dan rumput laut. Keduanya sudah dipromosikan kepada konsumen, namun konsumen lebih menyukai rasa telur asin sehingga varian ini yang sudah lebih banyak dipasarkan (Gambar 2). Dengan demikian, terdapat penambahan dua inovasi varian rasa baru melalui program ini, yang semula hanya memiliki empat varian rasa.

Program ini juga telah menghasilkan satu inovasi kemasan baru berbentuk box berbahan kertas yang dicetak sebanyak 1000 pcs. Kemasan didesain menggunakan logo baru yang lebih sederhana dilengkapi gambar maskot merek sehingga lebih eye catching untuk branding. Dari aspek ekonomi, kemasan ini lebih ekonomis hanya Rp2.300/pcs. Dengan kemasan baru ini mitra dapat menurunkan biaya pembelian kemasan lebih dari 100\%, di mana harga kemasan yang biasa digunakan adalah Rp5.500/ pcs (250 g, varian ukuran yang paling banyak diproduksi). Namun demikian, kemasan lama

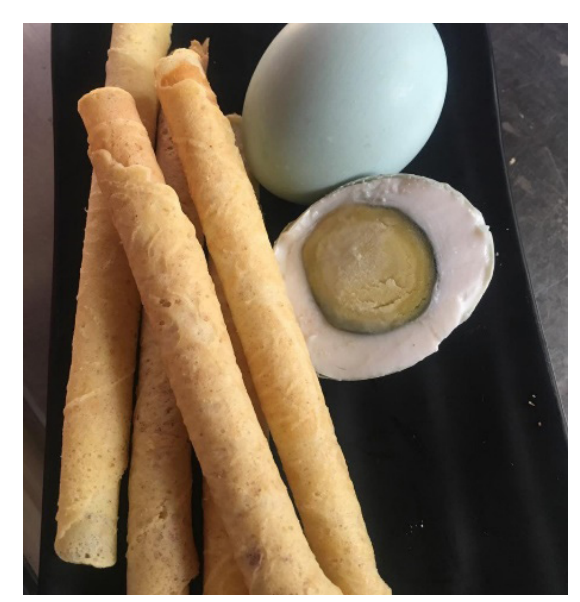

Gambar 2. Varian Rasa Baru Eggroll Kentang Salted Egg 


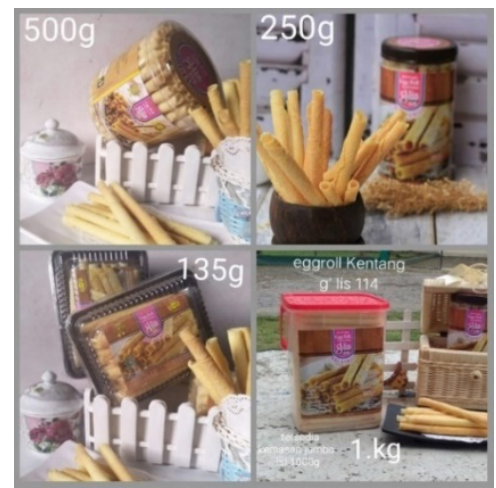

Gambar 3. Kemasan Sebelum Program

tetap digunakan sebagai pilihan variasi ukuran. Gambar 3 dan 4 menunjukkan perbedaan berbagai kemasan lama dan kemasan baru dari hasil program.

Melalui program ini, mitra juga telah mengalami peningkatan pada jumlah aset. Adapun penambahan aset perusahaan yang baru meliputi: 1 unit laptop, 1 unit mixer, 1 unit oven, 3 unit cetakan eggroll, 1 unit hand mixer, beberapa unit wadah penyimpana bahan baku, 1 unit kompor gas, dan 1 set alat printer kasir untuk toko milik UMKM.

\section{Aspek Manajemen Pemasaran}

Secara umum, aspek manajemen pemasaran mendapatkan porsi lebih banyak dalam pembinaan UMKM mengingat bahwa saat ini UMKM mengalami penurunan penjualan yang juga berdampak pada penurunan pendapatan dan modal kerja, sehingga solusi yang dibutuhkan mitra saat ini adalah meningkatkan jangkauan pemasaran dan penjualan. Dampak pembinaan manajemen pemasaran terhadap mitra dijelaskan pada Gambar 5. Hasil menunjukkan bahwa setelah program, mitra mengalami peningkatan pada aspek pengetahuan dan keterampilan manajemen

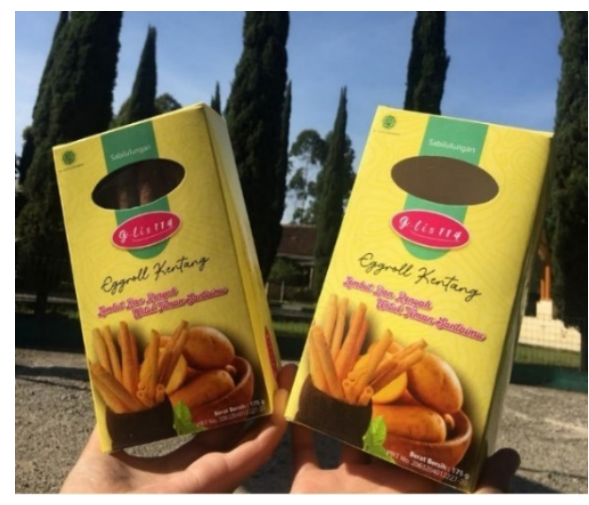

Gambar 4. Kemasan Baru Setelah Program

pemasaran online, serta peningkatan pada implementasi pengelolaan toko di marketplace dan sosial media. Aspek pengetahuan dan keterampilan pengelolaan toko online yang telah diperoleh mitra antara lain 1) pengelolaan toko online serta teknik pengemasan untuk memaksimumkan pelayanan kepada konsumen, 2) cara aktivasi iklan di toko online, 3) strategi mengelola konten (visual dan verbal) di halaman toko online dan mengelola pelanggan, 4) praktik mengelola toko online dari mulai upload foto produk dan deskripsi sampai pengisian saldo untuk iklan, dan 5) praktik pengelolaan iklan.

Adapun pengetahuan dan keterampilan pengelolaan sosial media meliputi: 1) manajemen konten untuk tujuan promosi di sosial media; 2) cara aktivasi iklan di sosial media; 3) cara promosi produk di sosial media menggunakan Social Media Influencer dan teknik menentukan Influencer yang tepat sesuai dengan kategori produk; dan 4) praktek iklan dan mengelola iklan di Instagram. UMKM telah membuka akun toko online di Tokopedia, Shopee, dan Bukalapak, namun karena keterbatasan SDM pengelola, maka pengelolaan toko online akhirnya hanya difokuskan di Tokopedia. Demikian halnya dengan pengelolaan sosial

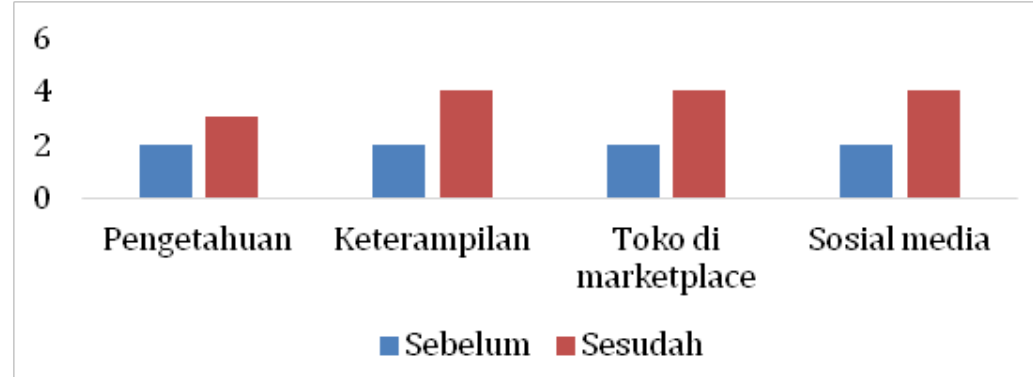

Gambar 5. Dampak pada Aspek Manajemen Pemasaran UMKM Sebelum dan Sesudah Program 
media, yang semula diarahkan untuk memiliki fan page merek, namun juga karena keterbatasan SDM pengelola sehingga saat ini diarahkan agar promosi dipusatkan di Instagram milik owner yang dapat diakses di @heros_eggroll, sehingga owner dalam hal ini juga berperan sebagai influencer dalam kategori influencer wirausaha. Terdapat perbedaan fungsi antara marketplace dan sosial media, di mana marketplace berfungsi sebagai saluran penjualan, sedangkan sosial media berfungsi sebagai saluran promosi atau branding sehingga akun sosial media juga terkoneksi dengan marketplace. Gambar
6 dan 7, menunjukkan tampilan toko online mitra sebelum dan sesudah program, di mana sebelum program hanya ada satu postingan foto produk tanpa adanya deskripsi produk dalam hal ini mitra belum memahami teknik mengelola halaman toko untuk meningkatkan statistik kunjungan. Jika hanya satu foto produk tanpa deskripsi tentunya menyebabkan toko menjadi kurang trusted untuk konsumen. Setelah program, produk yang ditampilkan lebih beragam meliputi berbagai variasi rasa dan ukuran kemasan, dan semua dilengkapi dengan deskripsi produk secara lengkap.

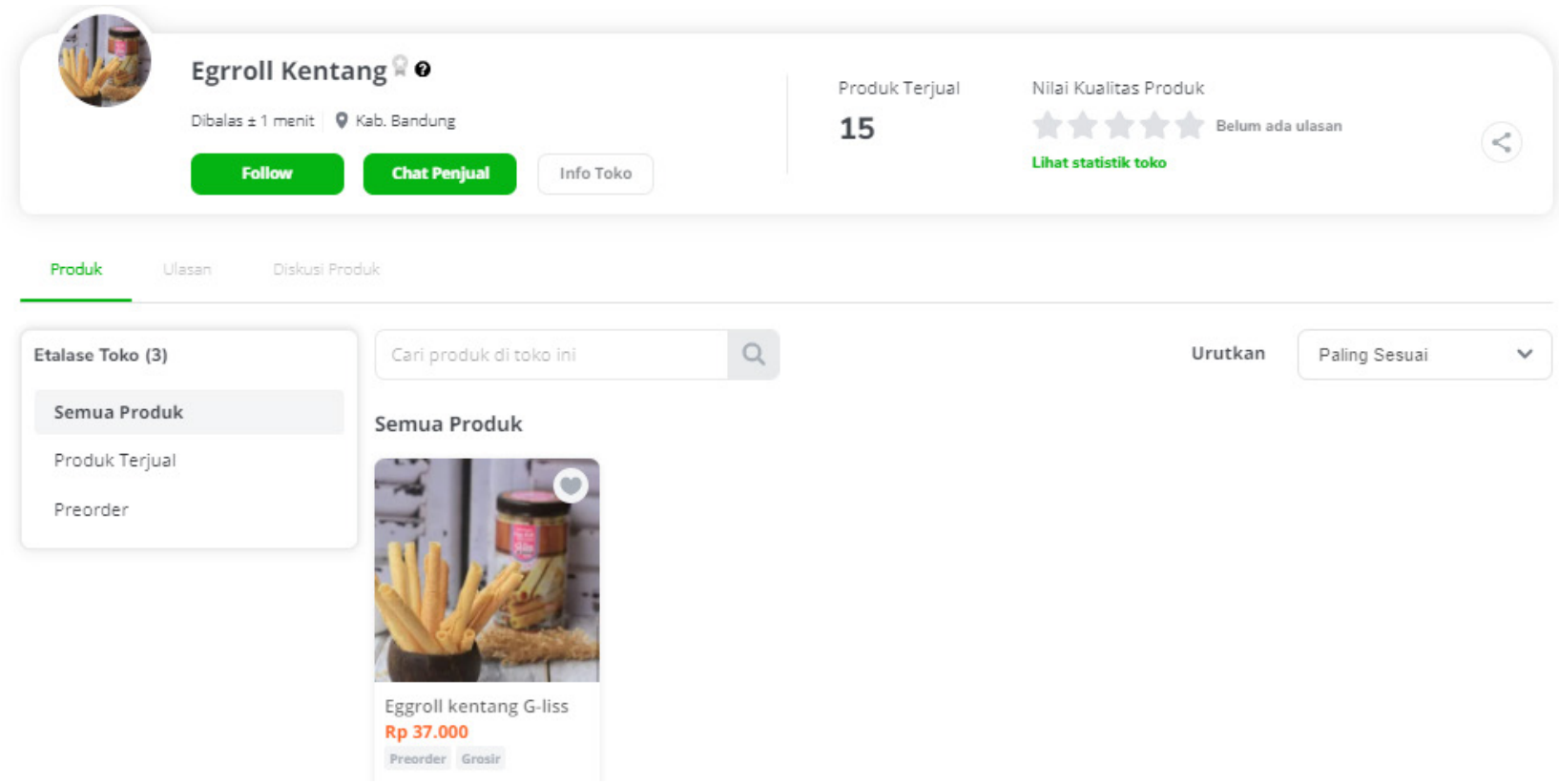

Gambar 6. Halaman Depan Toko Online Mitra Sebelum Program
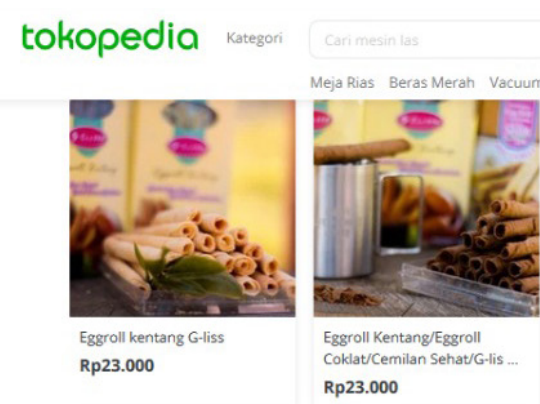

Rp23.000
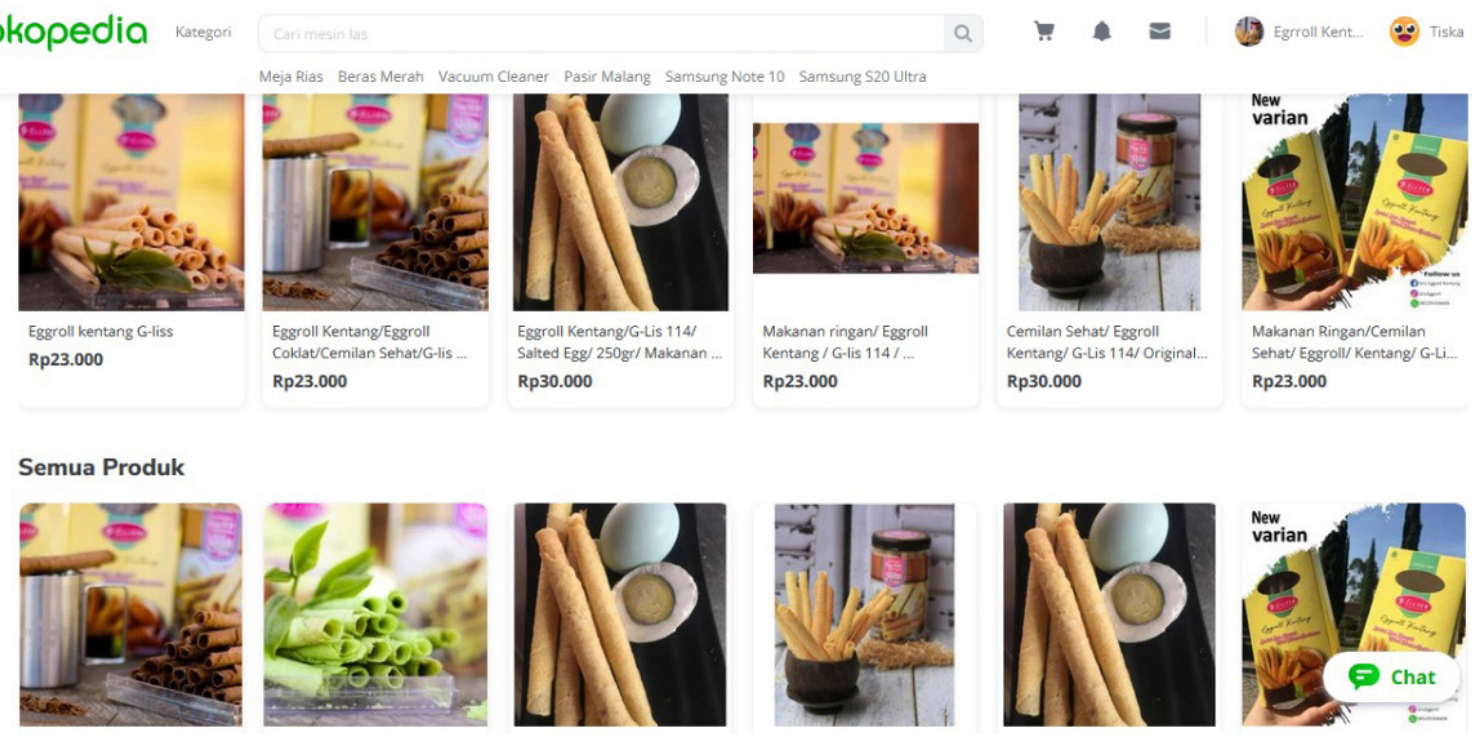

Gambar 7. Halaman Toko Online Mitra Setelah Program 


\section{a. Pelatihan fotografi produk}

Dalam pemasaran online, kemampuan mitra dalam menyajikan konten visual yang menarik sangat penting, pelatihan fotografi ini telah memberikan pengetahuan dasar kepada mitra tentang fotografi produk seperti konsep foto, mengatur lihgting, dan teknik pengambilan foto dengan menggunakan kamera Handphone. Foto produk makanan yang menarik adalah yang dapat membangkitkan selera konsumen untuk mengkonsuminya, artinya dengan hanya melihat gambar, konsumen tertarik untuk membeli. Pelatihan ini dilakukan dalam bentuk praktik (Gambar 8) untuk memberikan pengalaman keterampilan kepada mitra sehingga ke depannya diharapkan pengambilan foto produk lebih terkonsep. Pelatihan ini dilaksanakan di Wayang Windu Park, salah satu ikon tempat wisata di Pangalengan untuk memberikan pesan sebagai produk oleh-oleh terhadap konsumen khususnya yang menyukai traveling.

UMKM juga diberikan pelatihan editing foto dengan menggunakan Canva dan magic marketing template yakni template foto editing berupa power point sehingga tampilan foto menjadi lebih menarik, baik untuk dipost di feed atau story sosial media ataupun di marketplace. Adapun pelatihan fotografi dengan melibatkan mahasiswa Universitas Muhammadiyah Bandung yang aktif di UKM Fotografi. Contoh gambar hasil pelatihan fotografi telah diposting di sosial media dan marketplace sebagaimana disajikan pada Gambar 7 dan 9.

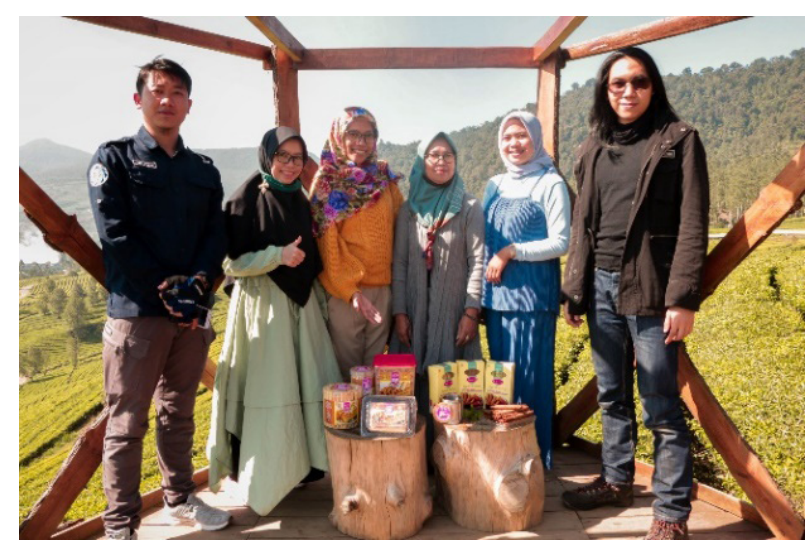

Gambar 8. Pelatihan Fotografi Bersama Mitra

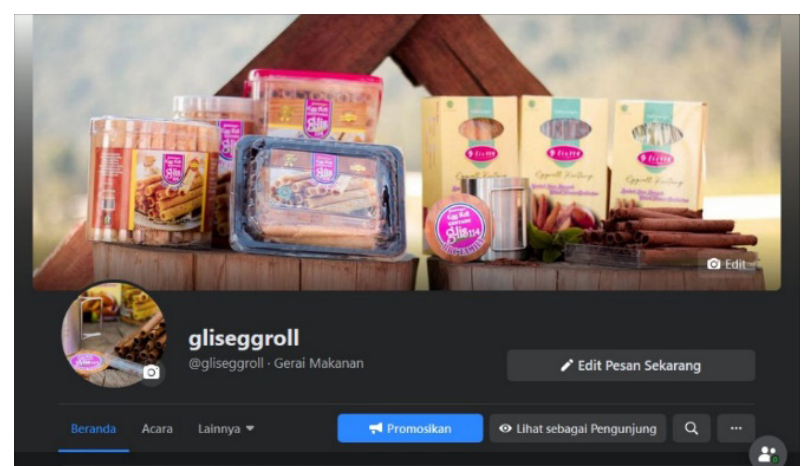

Gambar 9. Foto Produk di Halaman Fan Page Facebook Mitra

\section{b. Program iklan}

Program iklan telah dilakukan di Instagram owner yaitu @heros_eggroll. Pada awalnya mitra diarahkan untuk memiliki akun merek secara khusus, namun karena mitra lebih aktif di akun pribadi dan telah memiliki lebih dari seribu pengikut, maka kegiatan promosi produk lebih disarankan di akun personal owner. Artinya dalam hal ini owner berperan sebagai influencer untuk produk atau usahanya sendiri. Observasi awal menunjukkan bahwa rate engagement di sosial media mitra hanya sebesar 1,90\% yang dihitung berdasarkan rerata jumlah interaksi (suka, komentar, berbagi) terhadap jumlah follower, sehingga program iklan dibutuhkan untuk meningkatkan engagement dan memperluas jangkauan pasar kepada target segmen. Setelah program iklan, hasil analisa statistik iklan menunjukkan bahwa jumlah impresi (user yang melihat iklan) meningkat tajam sebesar 88\% dari impresi normal, di mana 98\% user yang dijangkau bukan merupakan follower, jumlah engagement juga meningkat sebesar 47\%. Dari jumlah engagement tersebut, sebesar 2,65\% melanjutkan pencarian informasi tentang produk ke toko online mitra. Namun demikian, konversi iklan terhadap penjualan di toko online masih $0 \%$ sehingga program iklan masih perlu terus dilakukan oleh mitra di mana jumlah engagement memiliki peluang besar untuk dikonversi menjadi penjualan melalui program iklan yang dilakukan secara berkala. Program iklan ini baru pertama kali dilakukan oleh mitra.

Kelemahan mitra untuk menghasilkan iklan yang efektif adalah pada penyajian konten secara umum di feed. Karena menggunakan 
akun pribadi, maka halaman akun lebih banyak berisi konten personal yang menyebabkan profil halaman menjadi kurang efektif untuk memberikan informasi lebih lanjut tentang merek saat user membuka profil akun pengiklan. Saat iklan ditampilkan di sosial media dan user tertarik, maka profil pembuat iklan adalah hal pertama yang akan dibuka, tujuannya adalah untuk mencari informasi lanjut tentang produk. Karena konten lebih banyak berisi konten kegiatan personal, maka pencarian informasi produk menjadi gagal dan tahapan keputusan pembelian berikutnya sangat mungkin tidak terjadi.

Program iklan juga dilakukan di Tokopedia pada akhir Oktober, yang meliputi iklan produk, iklan headline, dan promo voucher dalam bentuk cashback. Iklan produk bertujuan agar produk eggroll kentang mudah ditemukan di mesin pencari dengan kata kunci "cemilan", "cemilan sehat", atau "eggroll", di mana "cemilan" dan "cemilan sehat" merupakan kata kunci yang paling banyak digunakan oleh user ketika berbelanja makanan ringan di marketplace. Promosi dalam bentuk cashback telah dilakukan selama satu pekan, sedangkan iklan lainnya dibatasi oleh anggaran iklan sehingga selama kredit iklan di marketplace masih ada, maka iklan tetap berjalan secara otomatis. Dari hasil iklan selama satu pekan pertama saat data ini diambil, menunjukkan bahwa statistik kunjungan toko meningkat sangat tajam sebesar $3500 \%$, toko mulai banyak mendapatkan pesan chat dari calon pembeli bahkan diantaranya mereka yang tertarik untuk menjadi dropshiper atau reseller. Kemudian, pada awalnya, produk eggroll kentang ini tidak dapat ditemukan di mesin pencarian Tokopedia bahkan dengan kata kunci "eggroll", namun dengan kata kunci yang sama, produk ini sekarang mudah ditemukan di mesin pencari Tokopedia. Adapun dengan dua kata kunci lainnya, masih diperlukan upaya iklan yang lebih konsisten. Selanjutnya, dari statistik kunjungan telah menghasilkan konversi penjualan sebesar 4,3\% artinya ada pengaruh positif dari iklan yang dilakukan di Tokopedia terhadap tingkat penjualan produk mitra. Kelemahan mitra dalam pengelolaan toko online adalah jarang mengupdate atau merefresh toko yang menyebabkan potensi penurunan jumlah kunjungan, sulitnya produk ditemukan di halaman pertama mesin pencari bahkan termasuk jika iklan dilakukan, dan respon terhadap chat pelangan menjadi lambat sehingga menurunkan kinerja toko yang menyebabkan dampak negatif lebih lanjut menurunkan penjualan.

\section{c. Kinerja Produksi, Penjualan, dan Pendapatan Mitra}

Gambar 10, menunjukkan kinerja produksi dan penjualan mitra selama satu tahun terakhir sangat fluktuatif, di mana kapasitas produksi bersifat linier dengan penjualan dan pendapatan. Pada Januari sampai Maret 2020, penjualan menurun hampir 50\%, dengan penjualan terendah pada Maret dengan hanya terjual sekitar 200 pcs dan pendapatan sekitar Rp5.000.000. Pada bulan berikutnya, penjualan naik signifikan di mana penjualan tertinggi pada bulan Mei, bertepatan dengan momen

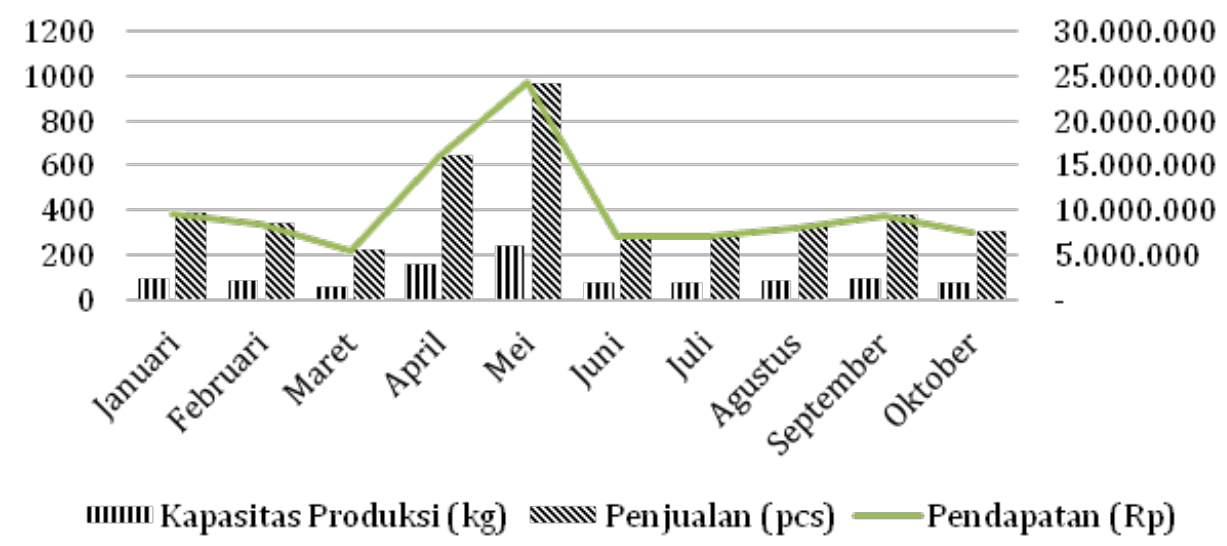

Gambar 12. Kinerja Produksi dan Penjualan Eggroll Kentang g-Lis 114 Periode Januari-Oktober 2020 (UMKM mitra, diolah 2020) 
idulfitri, dengan tingkat penjualan mendekati 1000 pcs dan pendapatan hampir mencapai 25 juta rupiah. Kenaikan ini dinilai normal karena permintaan produk makanan pada bulan Ramadan dan idulfitri umumnya sering mengalami kenaikan. Pada bulan Juni, penjualan kembali menurun signifikan, namun kembali naik secara lambat sampai September dengan tingkat pendapatan mencapai hampir 10 juta rupiah dan menurun kembali pada bulan berikutnya. Kenaikan tersebut tentunya didukung oleh upaya mitra yang terus meningkatkan promosi untuk menjangkau pasar yang lebih luas, baik dilakukan secara online melalui sosial media dan marketplace, maupun secara offline melalui jejaring UMKM yang dimiliki mitra. Selama program ini berlangsung, mitra juga telah menambah tiga mitra reseler/agen pemasaran baru.

\section{d. Survei kesadaran merek (brand awareness)}

Survei ini bertujuan untuk membantu mitra dalam mengukur tingkat kesadaran konsumen terhadap Eggroll Kentang g-Lis 114 yang selanjutnya dapat digunakan sebagai acuan untuk memberikan rekomendasi strategi pemasaran lebih lanjut kepada mitra. Survei dilakukan online pada 22 Oktober - 8 November 2020 dengan teknik random sampling terhadap 100 responden. Responden berumur 17-57 tahun, terdiri dari $66 \%$ wanita dan 34\% pria yang berdomisili di Bandung Raya (69\%), Jabodetabek (13\%), dan sisanya tersebar di berbagai wilayah lain. Mereka adalah penyuka cemilan (94\%) dan traveling (83\%).

Hasilnya menunjukkan bahwa hanya $27 \%$ responden yang pernah mendengar merek g-Lis 114, sedangkan mayoritas belum mendengar merek ini. Yang mereka rasakan tentang merek ini adalah sangat positif (15\%), positif $42 \%)$, netral (40\%), dan sisanya negatif (2\%) dan sangat negatif (1\%). Dari aspek iklan atau promosi, sebanyak 22\% pernah melihat iklan atau promosi merek ini melalui sosial media $(68,8 \%)$ dan di toko (1\%), sedangkan sisanya belum pernah melihat iklan atau promosi produk ini di manapun. Sebanyak 21\% responden pernah membeli produk ini, sedangkan 79\% belum pernah membeli. Mayoritas responden menyebutkan sangat tidak familier (25\%) dan tidak familier (46\%) terhadap merek ini, dan hanya sebagian kecil yang sangat familier (12\%), cukup familier (12\%) dan familier (5\%) terhadap merek ini.

Sebanyak 63\% responden pernah membeli produk eggroll dengan merek yang beragam. Dari yang berpengalaman membeli eggroll tersebut, 53\%-nya justru memikirkan merek eggroll lain saat mendengar nama produk eggroll. Adapun merek eggroll yang menurut responden paling populer adalah Monde (61,5\%), hanya 9,6\% yang menjawab g-Lis 114 paling populer, dan sisanya menyebutkan merek lain. Adapun media yang dinilai paling efektif untuk mereka dapat mengetahui informasi dan mengakses informasi tentang sebuah merek baru adalah sosial media (81\%), marketplace (13\%), televisi (4\%), koran dan word of mouth masing-masing $1 \%$.

Kesadaran merek setidaknya dapat diukur dari dua aspek, yakni brand recognition dan brand recall (Chandon, 2003; Perera \& Dissanayake, 2013). Berdasarkan hasil survei tersebut dapat disimpulkan bahwa kesadaran merek dari konsumen terhadap Eggroll Kentang g-Lis 114 masih rendah, dengan indikator:

1) Rendahnya brand recognition, di mana hanya $27 \%$ responden yang pernah mendengar nama merek ini dan hanya $22 \%$ yang pernah melihat merek ini melalui iklan. Selanjutnya, hanya $17 \%$ yang familier dan sangat familier terhadap merek ini dan 12\% cukup familier, sedangkan mayoritas menyebutkan tidak familier dan sangat tidak familier.

2) Rendahnya brand recall, yakni kemampuan konsumen untuk mengingat kembali sebuah merek saat dihadapkan pada pilihan merek dari kategori produk yang sama, di mana hanya 9,6\% responden yang mengingat g-Lis 114 sebagai top of mind sedangkan mayoritas dari mereka lebih mengingat nama merek produk eggroll lain.

Penelitian terdahulu telah menemukan bahwa kesadaran merek berpengaruh signifikan terhadap keputusan pembelian konsumen, dan ini sangat masuk akal sebab jika dilihat dari 
piramida tingkat pengetahuan merek, kesadaran merek merupakan pengetahuan merek yang paling dasar untuk meraih loyalitas konsumen sebagai pengetahuan merek tertinggi. Kesadaran merek terhadap konsumen dapat diciptakan melalui promosi, iklan, penjualan, hubungan masyarakat (public relation), dan pemasaran langsung.

Dengan demikian, rekomendasi untuk strategi pemasaran mitra adalah perlu memperkuat pengelolaan saluran pemasaran yang secara intensif mampu memberikan notifikasi, pengingat dan meyakinkan konsumen tentang merek, produk, atau layanan mereka agar lebih banyak penjualan. Hasil survei menunjukkan bahwa di era digital ini, konsumen lebih memilih sosial media sebagai sumber informasi suatu merek, yang telah menggeser posisi promosi dari mulut ke mulut dan bahkan iklan di televisi. Survei ini juga menunjukkan bahwa mayoritas responden yang mengenal merek Eggroll Kentang g-Lis 114 pertama mengetahui promosi atau iklannya dari sosial media. Artinya, sosial media telah menjadi saluran yang efektif untuk memperkenalkan merek ini kepada calon konsumen. Selanjutnya, mitra setidaknya dapat melakukan program iklan setiap 1-2 bulan sekali untuk menjangkau target konsumen yang lebih luas karena terbukti program iklan dapat menjangkau 98\% nonfollower, adapun promosi organik jika memiliki anggaran terbatas lebih direkomendasikan, namun diperlukan pengelolaan konten visual dan caption yang lebih menarik dan bermanfaat bagi target pasar untuk meningkatkan jumlah follower dan engagement.

\section{SIMPULAN}

Program pengabdian ini sudah berjalan efektif dengan mitra yang sangat kooperatif, sehingga dari aspek manajemen produksi, mitra telah mampu meningkatkan pengetahuan dan keterampilan dalam aspek manajemen produksi, jumlah varian rasa produk bertambah sebanyak dua varian, biaya produksi dapat diminimumkan melalui desain kemasan baru, dan bertambahnya jumlah aset perusahaan. Dari aspek pemasaran, mitra telah mendapatkan peningkatan pengetahuan dan keterampilan dalam manajemen pemasaran di marketplace dan sosial media, serta tren penjualan mulai ada peningkatan kembali yang tentunya berkorelasi positif terhadap tingkat pendapatan atau omset mitra.

Selama ini mitra masih mengandalkan penjualan dengan sistem konsinyasi yang terkadang pembayarannya tidak terjadwal, akibatnya adalah dapat mengganggu cash flow terutama karena saat ini mitra mengalami penurunan modal kerja. Sebagai rekomendasi, mitra perlu memperbaiki kontrak konsinyasi agar pembayaran lebih terjadwal setidaknya satu bulan sekali dan meningkatkan penjualan dengan sistem jual tunai. Meningkatkan jumlah pembelian individu, reseler atau dropshiper di marketplace merupakan salah satu solusi mitra untuk meningkatkan sistem jual tunai. Selanjutnya mengacu kepada hasil survei kesadaran merek, mitra perlu secara intensif mengelola sosial media sebagai saluran promosi baik melalui iklan/ads maupun organik dengan konten post baik untuk feed ataupun story yang lebih terkonsep. Adapun rencana kegiatan selanjutnya adalah tim fokus membantu mengembangkan pemasaran mitra dalam bentuk layanan konsultasi implementasi strategi pemasaran digital yang sudah diberikan melalui forum online yang sudah dibuat selama program, dan membantu menghubungkan UMKM mitra dengan pasar baru yang potensial.

\section{PERSANTUNAN}

Ucapan terima kasih dan apresiasi diberikan kepada berbagai pihak yang telah berkontribusi dalam pelaksanaan kegiatan ini yakni kepada dosen pembantu pelaksana kegiatan, tim mahasiswa pembantu lapangan, serta UMKM mitra yang sangat kooperatif selama pelaksanaan kegiatan. Ucapan terima kasih secara khusus diberikan sebesar-sebesarnya terutama kepada Kemenristek-BRIN sebagai pemberi dana program pengabdian kepada masyarakat ini. 


\section{REFERENSI}

Accenture. (2020). COVID-19: What to do Now, What to do Next How COVID-19 will Permanently Change Consumer Behavior Fast-Changing Consumer Behaviors Influence the Future of the CPG industry. Retrieved from https://www.accenture.com/_acnmedia/PDF-123/Accenture-COVID19-PulseSurvey-Research-PoV.pdf

Acosta, A. S., Crespo, A. H., \& Agudo, J. C. (2018). Effect of Market Orientation, Network Capability and Entrepreneurial Orienation on International Performance of Small and Medium Enterprises (SMEs). International Business Review, 27(6), 1128-1140. https://doi.org/10.1016/j. ibusrev.2018.04.004

AICD. (2020, May). How SMEs are Responding to the Covid-19 crisis. Retrieved May 26, 2020, from Article website: https://aicd.companydirectors.com.au/membership/company-directormagazine/2020-back-editions/may/how-smes-are-responding-to-the-covid-19-crisis

Al-Awlaqi, M. A., Aamer, A. M., \& Habtoor, N. (2018). The Effect of Entrepreneurship Training on Entrepreneurial Orientation: Evidence from a Regression Discontinuity Design on Micro-Sized Businesses. International Journal of Management Education, (July). https://doi.org/10.1016/j. ijme.2018.11.003

Barba-sánchez, V., \& Atienza-sahuquillo, C. (2018). Entrepreneurial Intention Among Engineering Students : The Role of Entrepreneurship Education. European Research on Management and Business Economics, 24(1), 53-61. https://doi.org/10.1016/j.iedeen.2017.04.001

Bouwman, H., Nikou, S., \& de Reuver, M. (2019). Digitalization, Business Models, and SMEs: How do Business Model Innovation Practices Improve Performance of Digitalizing SMEs? Telecommunications Policy, 43(9), 101828. https://doi.org/10.1016/j.telpol.2019.101828

Bouwman, H., Nikou, S., Molina-Castillo, F. J., \& de Reuver, M. (2018). The Impact of Digitalization on Business Models. Digital Policy, Regulation and Governance , 20(2), 105-124. https://doi. org/10.1108/DPRG-07-2017-0039

Casalino, N., Żuchowski, I., Labrinos, N., Munoz Nieto, Á. L., \& Martín, J. A. (2020). Digital Strategies and Organizational Performances of SMEs in the Age of Coronavirus: Balancing Digital Transformation with An Effective Business Resilience. SSRN Electronic Journal, (December). https://doi.org/10.2139/ssrn.3563426

Chadwick, I. C., \& Dawson, A. (2018). Women Leaders and Firm Performance in family Businesses: An examination of Financial and Nonfinancial Outcomes. Journal of Family Business Strategy, 9(4), 238-249. https://doi.org/10.1016/j.jfbs.2018.10.002

Chandon, P. (2003). Note on Measuring Brand Awareness, Brand Image, Brand Equity and Brand Value (pp. 1-10). pp. 1-10. Retrieved from https://flora.insead.edu/fichiersti_wp/inseadwp2003/2003-19. pdf

Curatman, A. (2016). Analisis Faktor-Faktor Pengaruh Inovasi Produk yang Berdampak pada Keunggulan Bersaing UKM Makanan dan Minuman di Wilayah Harjamukti Kota Cirebon. Jurnal Logika, XVIII(3), 61-75.

Dai, H., Robert, X., Liao, Q., \& Cao, M. (2015). Explaining Consumer Satisfaction of Services : The role of Innovativeness and Emotion in An Electronic Mediated Environment. Decision Support Systems, 70, 97-106. https://doi.org/10.1016/j.dss.2014.12.003

Hanifawati, T., Dewanti, V. W., \& Saputri, G. D. (2019). The Role Of Social Media Influencer On Brand Switching Of Millenial and Gen Z: A Study of Food-Beverage Products. Journal of Applied Management (JAM), 17(4). https://doi.org/10.21776/ub.jam.2019.017.04.07

Hanifawati, T., Ritonga, U. S., \& Puspitasari, E. E. (2019). Managing Brands' Popularity On Facebook: 
Post Time, Content, And Brand Communication Strategies. In Journal of Indonesian Economy and Business (Vol. 34). Retrieved from http://journal.ugm.ac.id/jieb

Hanifawati, T., \& Suryantini, A. (2015). Meningkatkan Daya Saing IKM Makanan melalui Inovasi Produk dan Kemasan. Prosiding Manajemen Dinamic UNNES. UNNES.

Hanifawati, T., Suryantini, A., \& Mulyo, J. H. (2017). Pengaruh Atribut Kemasan Makanan dan Karakteristik Konsumen terhadap Pembelian. Agriekonomika, 6(9), 73-86. https://doi.org/ http://dx.doi.org/10.21107/agriekonomika.v6i1.1895

Haryono, T., \& Marniyati, S. (2017). Pengaruh Market Orientation, Inovasi Produk, dan Kualitas Produk terhadap Kinerja dalam Menciptakan Keunggulan Bersaing. Jurnal Bisnis \& Manajemen, 17(7), 51-68.

Kabadayi, S., \& Price, K. (2014). Consumer-Brand Engagement on Facebook: Liking and Commenting Behaviors. Journal of Research in Interactive Marketing, 8, 169-202. https://doi.org/10.1108/ JRIM-12-2013-0081

Lamba, R. (2020). Impact of COVID-19 on Consumer Behavior in Indonesia. Retrieved from https:// www.mmaglobal.com/files/covid_-19_indonesia_sentiment.pdf

Ludwig, S. (2020, March). 9 Creative Ways Small Businesses Are Adapting to Coronavirus. Retrieved May 26, 2020, from Article website: https://www.uschamber.com/co/start/strategy/smallbusinesses-adapt-creatively-to-coronavirus

Mahendra, A. M., Djatmika, E. T., \& Hermawan, A. (2017). The Effect of Entrepreneurship Education on Entrepreneurial Intention Mediated by Motivation and Attitude among Management Students , State University of Malang , Indonesia. 10(9), 61-69. https://doi.org/10.5539/ies.v10n9p61

Muninger, M. I., Hammedi, W., \& Mahr, D. (2019). The value of Social Media for Innovation: A Capability Perspective. Journal of Business Research, 95(July 2017), 116-127. https://doi.org/10.1016/j. jbusres.2018.10.012

Perera, W., \& Dissanayake, D. M. . (2013). The Impact of Brand Awareness, Brand Association and Brand Perceived Quality on Female Consumers' Purcase Decision of Foreign Makeup Products (a Study on Youth Segment). International Conference on Business \& Information, (November 2013).

Popa, S., Soto-Acosta, P., \& Perez-Gonzalez, D. (2018). An Investigation of the Effect of Electronic Business on Financial Performance of Spanish Manufacturing SMEs. Technological Forecasting and Social Change, 136, 355-362. https://doi.org/10.1016/j.techfore.2016.08.012

Rahman, R. (2020). 37,000 SMEs hit by COVID-19 Crisis As Government Prepares aid - Business - The Jakarta Post. Retrieved May 26, 2020, from Article website: https://www.thejakartapost.com/ news/2020/04/16/37000-smes-hit-by-covid-19-crisis-as-government-prepares-aid.html

Razdan, R., Potia, A., Wintels, S., \& Dadwal, R. (2020). Perspectives on Covid-19 and implications for consumer and retail companies by McKinsey \& Company in association with MMA MMA Webinar Series. Retrieved from https://www.mmaglobal.com/files/webinars/20200408_-_indonesia_ consumer_covid-19_impact_and_response_-_webinar_vshare.pdf

Socialbakers. (2020). State of Social Media Report: The Impact of COVID-19. Retrieved from https:// www.socialbakers.com/blog/covid-19-impact-social-media

Susilawati, S., Falefi, R., \& Purwoko, A. (2020). Impact of Covid-19's Pandemic on the Economy of Indonesia. Budapest International Research and Critics Institute (BIRCI-Journal): Humanities and Social Sciences, 3(2), 1147-1156. https://doi.org/10.33258/BIRCI.V3I2.954.G1284

Takata, H. (2016). Effects of Industry Forces, Market Orientation, and Marketing Capabilities on Business Performance : An Empirical Analysis of Japanese manufacturers from 2009 to 2011 政. Journal of Business Research, 69(12), 5611-5619. https://doi.org/10.1016/j.jbusres.2016.03.068 
Hanifawati dan Listyaningrum - Peningkatan Kinerja UMKM Selama Pandemi Covid-19 ...

Yannopoulos, P. (2011). Impact of the Internet on Marketing Strategy Formulation. International Journal of Business and Social Science, 2(18). Retrieved from www.ijbssnet.com

Zuhal. (2013). Gelombang Ekonomi Inovasi. Jakarta: Gramedia Pustaka Utama. 